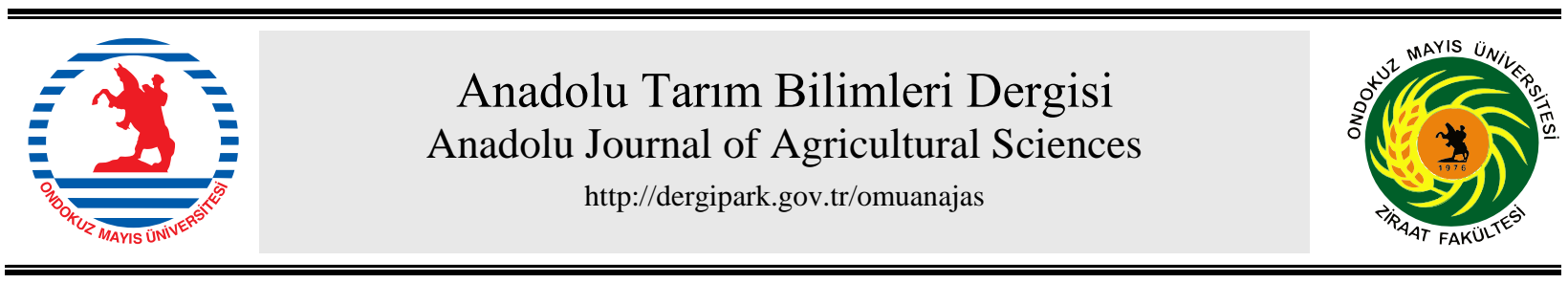

Araştırma/Research

Anadolu Tarım Bilim. Derg./Anadolu J Agr Sci, 35 (2020)

ISSN: 1308-8750 (Print) 1308-8769 (Online)

doi: 10.7161/omuanajas.614757

\title{
Afşin-Elbistan ovası'nda sulu ve kuru tarla arazilerde kapitalizasyon oranı ve arazi değerlerinin tespiti
}

\author{
Cuma Akbay ${ }^{\mathrm{a}^{*}}$ \\ ${ }^{a}$ Kahramanmaraş Sütçü Imam Üniversitesi, Ziraat Fakültesi, Tarım Ekonomisi Bölümü, Kahramanmaraş, Turkey
}

*Sorumlu yazar/corresponding author: cakbay@ksu.edu.tr

Geliş/Received 03/09/2019 Kabul/Accepted 05/03/2020

\begin{abstract}
ÖZET
Bu çalışmanın amacı, Türkiye'nin elektrik enerjisi üretiminde önemli yeri olan, Termik Santrallerin bulunduğu, Kahramanmaraş ili Afşin-Elbistan ovasındaki arazilerin kapitalizasyon oranını, net gelirini ve maliyetlerini belirlemektir. Araştırmada tabakalı örnekleme yöntemiyle seçilen 118 tarım işletmesinden elde edilen veriler kullanılmıştır. Araştırma sonucunda, kullanılabilir kapitalizasyon oranı sulu alanlarda \%5.76; kuru alanlarda ise \%5.21 olarak tespit edilmiştir. İncelenen işletmelerde işletme sahiplerinin arazilerine biçtikleri değer ile araştırmada hesaplanan değerler arasındaki fark sulu arazilerde \%2.66 iken; kuru arazilerde \%32.36'dır. Net gelir yöntemine göre hesaplanan değer, işletme sahiplerinin arazilerine biçtikleri değerden daha yüksek çıkmıştır. Araştırmada hesaplanan kapitalizasyon oranları ve elde edilen arazi değerleri, bölgede uygulanacak kamulaştırmalarda kamu kurumları ile yargı organlarına önemli katkılarda bulunacaktır.
\end{abstract}

Determination of capitalization rate and land appraisel in irrigated and dry farmland in Afşin-Elbistan plain

\section{ABSTRACT}

The purpose of this study is to determine the capitalization rate, net income and costs of land in Kahramanmaraş Afşin-Elbistan plain, which is an important place in Turkey's electricity production. In this research, data obtained from 118 agricultural farms selected by stratified sampling method were used. As a result of the research, the applicable capitalization rate was $5.76 \%$ in irrigated areas; and $5.21 \%$ in dry areas. While the difference between the value given to the land by the landowner and the calculated values in the research is $2.66 \%$ in irrigated lands; $32.36 \%$ on dry land. The value calculated according to the net income approach was higher than the value that owners value their land. The capitalization rates and land values calculated in the research will make significant contributions to the public institutions and judicial bodies in the expropriations to be implemented in the region.

Anahtar Sözcükler:

Değer biçme, Kapitalizasyon oran Gelir yöntemi Arazi değeri Afşin-Elbistan ovası
Keywords: Appraisal Capitalization rate Income method Land value Afşin-Elbistan plain 


\section{Giriş}

Türkiye'de, kırsal ve kentsel alanda ikamet eden bireylerin refah seviyelerinin arttırılması amaciyla kamu yararına yapılan yatırımlardan dolayı, özel ve tüzel kişilere ait taşınmaz malların kamulaştırılması söz konusu olmaktadır. Kamulaştırmaların mevcut yasalara uygun şekilde yerine getirilmesi ve kamulaştırma bedelinin hesaplanmasında gerçek değerlere yakın tahminler yapılması büyük önem taşımaktadır (Kılıç, 2011a).

Afşin ve Elbistan ilçeleri, Kahramanmaraş il merkezinden yaklaşık $160 \mathrm{~km}$ uzaklıkta birbirine komşu iki büyük ilçedir. Her iki ilçenin ekonomisi tarıma ve sanayiye dayalıdır. İlçe toprakları üzerinde bulunan Afşin-Elbistan ovası, Türkiye'nin dördüncü büyük ovası niteliğindedir. Bölgede yetiștirilen en önemli tarım ürünleri; buğday, şekerpancarı, ayçiçeği, nohut, arpa ve fasulyedir. Bölgenin iki büyük kuruluşu olan şeker ve tuğla fabrikaları, bölgenin gelişmesinde büyük öneme sahiptir.

Gelir yöntemiyle arazi değerinin hesaplanmasında, gelir ve arazi değerlerini tahmin etmek için alanda detaylı çalışma yapılarak, tarımsal üretimle ilgili girdi ve çıktılar, arazi piyasası verileri, ilgili kamu ve özel kuruluşların verilerinin toplanması ve bütün bu verilerin birlikte analiz edilmesi zorunludur. Türkiye elektrik ihtiyacının yaklaşı \%10'unu karşılayan Afşin-Elbistan Termik santrali araştırma alanı içerisinde bulunmaktadır.

Bölgede, termik santraller için gerekli olan kömürün çıkarıldığı alanlar ile kül depolama alanlarının kamulaştırılması nedeniyle, termik santraller çevresinde bulunan arazilerin gelirlerinin analizlerinde ve değerlendirilmesinde kullanılabilecek kapitalizasyon oranının belirlenmesi için, arazilerin yıllık ortalama net gelirleri ve birim arazi değerlerinin saptanması gerekmektedir. Son yıllarda, bölgede önemli sayıda kamulaştırma faaliyetleri yapılmakta olup, bu kamulaştırmalarda genellikle çok farklı teknikler uygulanmakta ve kamulaştırma için gerekli olan kapitalizasyon oranı rastgele belirlenmektedir. Oysaki kamulaştırmalarda kapitalizasyon oranını olması gerekenden daha düşük veya yüksek gösterilmesi, net gelirlerin hesaplanmasında sadece ana ürünün alınması; buna karşıllk yan ürünlerin (örneğin saman) dikkate alınmaması, maliyetlerin hesaplanmasında idari ücret karşıllı̆ı ve sermaye faiz oranlarının kullanılmaması ve bu konularla ilgi çeşitli yargı kararlarının bilirkişilerce dikkate alınmaması gibi birçok problemle karşılaşılmaktadır.

Türkiye'de kamulaştırma kapsamındaki taşınmaz mallarda değerleme işlemleri, Kamulaştırma Kanunu'nca belirtilen esaslar çerçevesinde, kamu kurumlarında oluşturulan kıymet takdiri komisyonları ve mahkemenin görevlendirdiği bilirkişiler tarafindan yapılmaktadır. Kamulaştırma Kanunu'na göre, arsa vasfindaki taşınmazlarda kamulaştırma bedelinin belirlenmesinde emsal, arazide ise gelir esasına göre değer biçilmektedir (Kılıç, 2011a).

Türkiye'de değişik bölgelerde ve çeşitli arazi nevileri için tarımsal kıymet takdiri ve Kapitalizasyon oranını belirlemeye yönelik çok sayıda araştırma yapılmıştır (Demircan ve Orhan, 1992; Keskin, 1994, 2003; Sayllı ve Esengün, 1996; Aktaş, 2000; Akay ve ark., 2001; Engindeniz, 2001; Aslan ve Esengün, 2002; Oğuz ve Ünal, 2004; Karakayacı ve Oğuz, 2006, Aydın ve Akay, 2008; Tanrıvermiş ve Aliefendioğlu, 2008; Tanrıvermiş ve ark., 2008; Neupane ve Gustavson, 2008; Başer ve Kılıç, 2016; Dağdemir ve ark., 2018; Kılıç ve ark., 2019). Yapılan çalışmalar incelendiğinde hesaplanan kapitalizasyon oranları, arazi satış değerleri ve arazi değerini etkileyen farklılıklardan dolayı bölgeler, iller ve uygulanan üretim desenleri itibariyle farklılıklar göstermektedir. Örneğin Tokat'ta yapılan çalışmalarda, kapitalizasyon oranları kuruda 3,06 ile 3,41 arasında; suluda ise 3,88 ile 5,90 arasında değişim göstermiştir (Sayılı ve Esengün, 1996; Akay ve ark., 2001; Aktaş ve Akay, 2001; Aydın ve Akay, 2008; Avcı ve Akay, 2012). Diğer bölgelerde yapılan çalışmalara bakıldığında, kapitalizasyon oranları kuru ve sulu alanlar için; Adana'da sırasıyla 4.97 ve 5.5 (Demircan ve Orhan, 1992), Denizli'de 5.83 ve 5.03 (Gündoğmuş ve Taşç, 2017), Bursa'da 5.75 ve 4.83 (Yalçın ve ark., 2018), Ağrı'da 5.7 ve 5.31 (Dağdemir ve ark., 2018), Eskişehir'de, 6.92 ve 7.84 (Keskin, 1994), Erzurum'da 10.94 ve 11.96 (Birinci, 1997), Konya'da ise 7.0 ve 6.02 (Karakayacı ve Oğuz, 2006) olarak belirlenmiştir. Bölgesel farklılığın dışında, kapitalizasyon oranlarındaki farklılıkların en önemli nedenleri; farklı yöntemlerin kullanılması ve üretim desenlerinin, arazi gelirlerinin, maliyetlerin ve arazi satışlarının zamanla değişim göstermesidir. Kamulaştırma, toplulaştırma çalışmaları ve banka ipoteği gibi birçok farklı amaç için değerleme çalışmasına konu olan tarım arazisi; eğim, taşlılık, verim gibi bazı özelliklere sahiptir. Her bir parselinin kendine has özellikleri arazi fiyatını artırmakta ya da azaltmaktadır (Başer ve ark., 2019).

$\mathrm{Bu}$ çalışmanın amacı; Türkiye'nin enerji üretiminde önemli yeri olan termik santrallerin bulunduğu AfşinElbistan ovasındaki taşınmazların kapitalizasyon oranı, net gelir ve maliyetlerini hesaplamaktır. Bu çalışmanın öncekilerden fark1, kapitalizasyon oranının hesaplanmasina ek olarak farklı münavebe uygulamalarında ve kapitalizasyon oranlarında elde edilen arazi değerinin hesaplanmış olmasıdır. Kapitalizasyon oranı ve buna göre arazi değerlerinin tahmin edilmesi, bölgede uygulanacak kamulaştırmalarda kamu kurum ve yarg1 organlarına önemli katkılarda bulunacaktır.

\section{Materyal ve Yöntem}

Tarımsal kıymet takdiri yapılan örnek arazilerin seçiminde, Afşin-Elbistan Termik santralinin 
çevresindeki son yıllarda satı̧̧ gerçekleştirilen tarım arazileri alınmıştır. $\mathrm{Bu}$ amaçla seçilen tarım ürünleri bölgenin üretim deseninde yer alan buğday, şekerpancarı, ayçiçeği, mısır, arpa ve nohuttur. Araştırmanın anket uygulaması Haziran-Eylül 2011 tarih aralığında yapılmıştır.

Afşin Elbistan A ve B Termik Santrallerinin çevrelerindeki köylerde işletme sahipleriyle karşıllkkl görüşme yoluyla anketler yapılmıştır. İncelenen yerleşim yerlerindeki arazilerin kullanıcıları ile karşılıklı görüşme yoluyla anket yapılarak veriler toplanmıştır.

Çalışmanın amacı bölgede sulu ve kuru tarla arazilerinde arazi değerlerinin belirlenmesi olduğundan, bölgede bulunan köylerin termik santrale olan uzaklıkları da dikkate alınarak 10 köy gayeli örnekleme yöntemiyle belirlenmiștir. Bu köylerde faaliyet gösteren 773 tarım işletmesi örneğe girebilecek populasyonu oluşturmuş̧ur. Örnek işletme seçiminde tabakalı tesadüfî örnekleme yöntemi kullanılmıştır (Yamane, 1967):

$$
n=\frac{N z^{2} \sigma^{z}}{d^{2}(N-1)+z^{2} \sigma^{2}}
$$

Araştırmada, \%10 hata ve \%95 güven sınırları kullanılarak örnek hacmi 118 tarım işletmesi olarak belirlenmiștir.

Örnek köylerin seçiminde, Afşin-Elbistan Ovasında yer alan termik santral civarında bulunan köylerin seçilmesine dikkat edilmiştir. Anket yapılacak işletmelerin seçiminde ise köydeki toplam işletme sayısı, arazi genişliği, arazilerde sulu ve kuru tarım yapılıp yapılmaması gibi kriterler kullanılmıştır.

Alım-satımı yapılan arazilerin tespitinde İlçe Tapu Müdürlüğü Kayıtları kullanılmıştır. Tapu kayıtlarında alım satım değerlerinin olduğundan çok düşük gösterilmesi nedeniyle, bu tapu kayıtları sadece alım satım yapılan işletmelerin tespiti amacıyla kullanılmıştır. Son üç yıl içerisinde alım-satımı yapılan araziler her köy için tespit edilerek, gayeli olarak o köyü temsil ettiği düşünülen sulu tarım arazilerinde 27 , kuru tarım arazilerin de ise 13 olmak üzere toplam 40 işletmeyle anket uygulaması yapılmıştır. İncelenen yerleşim yerlerinde fiilen alım satımı yapılmış olan arazilerin alıcısı veya satıcisiyla yapılacak anket çalışmasında, alım-satımı yapılan arazilerin satış değerleri, özellikleri ve ödeme koşullarına ilişkin veriler toplanmıştır.

Kamulaştırma Kanunu'nun 11. Maddesinin 3. Fıkrasının (f) bendi gereğince "tarımsal arazilerde taşınmaz mal veya kaynağın kamulaştırma tarihindeki mevkii ve şartlarına ve olduğu gibi kullanılması halinde getireceği net gelirine göre değerlendirilmesi” gerektiği belirtilmiştir (Anonim, 2019). Bu bağlamda, bir taşınmazın kıymet takdirinde, gelir yöntemine göre taşınmaz değerinin belirlenebilmesi için öncelikle taşınmazın yıllık ortalama net geliri (rantı) (R), yörede geçerli olan kapitalizasyon oranı (f) saptanır ve daha sonrada elde edilen rant kapitalizasyon oranına bölünerek taşınmazın değeri (D) bulunmaktadır:

$$
\begin{aligned}
& D=\frac{\text { Rant }}{\text { Kapitalizasyon oran } 1} \\
& D=\frac{R_{1}}{(1+f)^{1}}+\frac{R_{2}}{(1+f)^{2}}+\frac{R_{3}}{(1+f)^{3}}+\ldots \ldots+\frac{R n}{(1+f)^{n}}
\end{aligned}
$$

Tarım arazilerinin gelir yöntemine göre değerlerinin takdiri için, mutlaka kapitalizasyon oranı (f) ve taşınmazların net geliri bilinmelidir. Uygulamada bu yaklaşımın kullanımında "Rant" ve "kapitalizsayon oranının" belirlenmesi büyük önem taşımaktadır. Yukarıdaki formüldeki R, işletme analizi ile doğru olarak belirlenebildiği halde, f'nin saptanması oldukça güç olmaktadır. Kapitalizasyon oranı, bölgelere, şehirlere, arazilere ve arz ve talebe göre değişmektedir. Talebi ve dolayısıyla değeri yüksek olan arazinin kapitalizsayon oranı daha düşüktür.

Arazinin rantı (net geliri) ile o arazinin satış değeri arasındaki oran olarak tanımlanan kapitalizasyon oranı, belli bir bölgede aynı yıl içerisinde aynı tür tarımsal üretimin yapıldığı, aynı vasıf ve karakterdeki arazinin gerçek satı̧ bedeli ile net geliri belirlendikten sonra oranlanarak bulunur. Bir yıl içerisinde bölgede satışı yapılan tüm arazilerin dekar başına fiyatı tespit edilip ortalama dekar fiyatı bulunduktan; aynı arazi parçalarının her birinin dekar başına net geliri de saptanıp, yine ortalama net geliri belirlendikten sonra her iki ortalama rakamın birbirine olan oranı, yüzde ile ifade edilen kapitalizasyon oranıdır. Bulunan bu oran, aynı yıl içerisinde o bölgede cari ortalama kapitalizasyon oranını ifade eder (Engindeniz, 2001; Karakayacı ve Oğuz, 2006; Kılıç, 2011b; Dağdemir ve ark., 2018; Kılıç ve ark., 2019).

Kapitalizasyon oranı bölgedeki benzer araziler karşılaştırılarak saptanabilir. Bunun için benzer birçok arazinin güncel satış fiyatlarının bilinmesi gerekir. Kapitalizasyon oranı $(f)$, satışı gerçekleșmiş olan emsal arazi parsellerine ait net gelirler toplamının, arazi parselinin satış değerleri toplamına bölünmesiyle elde edilmektedir (Kılıç, 2011b). Bu oran aşağıdaki gibi formüle edilebilir.

$f=\frac{\text { Toplam Rant (Net Gelir) }}{\text { Toplam Arazi Pazar Degerleri }}=\frac{R_{1}+R_{2}+R_{\mathrm{a}}+{ }^{\cdots}{ }_{n}+R_{n}}{D_{1}+D_{2}+D_{3}+{ }_{n}+D_{n}}=\frac{\sum_{i=1}^{n} R}{\sum_{i=1}^{n} D}$

Formülde $R_{1}$, satışı gerçekleşen emsal arazi parselinin yıllık net gelirini; $\mathrm{D}_{1}$ parsellerin satış fiyatlarını ifade etmektedir. Formülde $n$ ise, satıșı gerçekleşen emsal parsel sayısını göstermektedir (Demircan ve Orhan, 1991; Rehber, 1999; Engindeniz, 2001; Karakayacı ve Oğuz, 2006; Kılıç, 2011b).

Gelirlerin kapitalizasyonu ile bulunacak değer, arazinin gelir değeri veya kullanım değeri olmaktadır. Arazinin gerçek değerine ulaşılabilmesi için ayrıca bazı ayarlamaların yapılması gerekecektir. Arazinin kıymetini etkileyebilecek bazı olumlu ve olumsuz faktörler dikkate alınacaktır. Bu faktörlerden bazıları şunlardır: arazinin kente veya kasabaya olan uzaklığı, ulaşım olanakları, arazinin serbest olarak alınıp satılabilmesi, arazinin kadastro çalışmasının yapılmış 
olması, toprağın yapısının düzgün olması, sulama kolaylığı, münavebe sisteminin değiştirilebilirliği olarak sıralanabilir. Arazi, bulunduğu bölgeye oranla belirtilen faktörler yönünden olumlu özelliklere sahip ise, kapitalizasyon oranı azalacak, aksi durumda ise yükselecektir. Araştırmada, sulu ve kuru araziler için ayrı ayrı kapitalizsayon oranları hesaplanmıştır. Hesaplamalarda arazide uygulanan yaygın münavebe sistemi dikkate alınmıştır. Ürün verimi, fiyatlar ve maliyetler bizzat arazi sahipleriyle yapılmış anketler sonucunda belirlenmiştir. Ancak karşıllaştırma yapmak amacıyla bölgedeki Tarım İl ve İlçe Müdürlüğü kayıtları da kullanılmıştır (Rehber, 1999; Kalkan, 2008). Net gelir hesaplamalarında, bölgede daha önceki yıllarda yapılan bilirkişi raporlarında yer almayan genel yönetim giderleri, sermaye faiz oranları ve yan ürün gelirleri dikkate alınmıştır.

\section{Bulgular ve Tartışma}

\subsection{Sulu ve kuru tarla arazilerinde kapitalizasyon oraninin tespiti}

İncelenen tarla arazilerinde kapitalizasyon oranı, sulu ve kuru tarım arazileri için hesaplanmıştır. Kapitalizasyon oranı, arazinin rantı ile gerçek satış değeri arasındaki orandır. Bölgede son 3 yıl içerisinde satışları yapılan sulu ve kuru tarla arazileri için esaplanan rantlar ile üreticilerin beyanlarına göre alınan gerçek satış değerleri tablo halinde verilmiştir (Çizelge 1). Satış1 gerçekleşen arazilerin yıllık ortalama net gelirleri, sulu tarla arazilerinde ortalama 326,6 TL/da iken, kuru tarım arazilerinde 59.2 TL/da'dır. Dolayısıyla sulu arazilerden elde edilen net gelirler, kuru arazilerden elde edilen net gelirlerden yaklaşı olarak 5.5 kat daha fazladır. Alım-satımı gerçekleştirilen arazilerin, üretici beyanlarına göre ortalama pazar değeri ise sulu arazilerde $5666.7 \mathrm{TL} / \mathrm{da}$, kuru arazilerin ise 1135.0 TL/da olarak tespit edilmiştir (Çizelge 2). Sulu arazilerin ortalama birim pazar değeri, kuru arazilerin yaklaşık 5 katı daha yüksek tespit edilmiştir. Sulu arazi değerlerinin bu kadar yüksek olmasının en önemli nedeni, bölgede kamulaştırma nedeniyle sulu arazi varlığının giderek azalması olarak belirtilmiştir. Çizelge 1 ve 2'de hesaplanmış olan değerler denklemde yerine konulduğunda, sulu alanlar için Kapitalizasyon oranı;

$f_{\text {sulu }}=\frac{\text { Toplam Rant (Net Gelir) }}{\text { Toplam Arazi Pazar Degerleri }}=\frac{8818,09}{153000,00}=0,0576=\% 5,76$

Kuru araziler için kapitalizasyon oranı ise;

$f_{\text {huru }}=\frac{\text { Toplam Rant (Net Gelir) }}{\text { Toplam Arazi Pazar Degerleri }}=\frac{769,18}{14755,00}=0,0521=\% 5,21$ olarak tespit edilmiştir.

Çizelge 1. İncelenen tarım işletmelerinde satışı gerçekleştirilen sulu tarla arazilerinin rantları, değerleri ve hesaplanan Kapitalizasyon oran 1

Table 1. Land rant, values and calculated capitalization rate of irrigated farmland sold in the agricultural farms

\begin{tabular}{ccc}
\hline & $\begin{array}{c}\text { Arazi gerçek satış değerleri } \\
(\mathrm{TL} / \mathrm{da})\end{array}$ & $\begin{array}{c}\text { Satış yapılan arazilerin yıllık } \\
\text { net gelirleri (TL/da) }\end{array}$ \\
\hline İşletmeler ortalaması & 5666.67 & 326.60 \\
Toplam & 153000.00 & 8818.09 \\
Kapitalizasyon oranı & & $=0.0576(\% 5.76)$ \\
\hline
\end{tabular}

Çizelge 2. İncelenen tarım işletmelerinde satışı gerçekleștirilen kuru tarla arazilerinin rantları, değerleri ve hesaplanan Kapitalizasyon oranı

Table 2. Land rant, values and calculated capitalization rate of dry farmland sold in the agricultural farms

\begin{tabular}{ccc}
\hline & $\begin{array}{c}\text { Arazi gerçek satış değerleri } \\
\text { (TL/da) }\end{array}$ & $\begin{array}{c}\text { Satış yapılan arazilerin yıllık } \\
\text { net gelirleri (TL/da) }\end{array}$ \\
\hline $\begin{array}{c}\text { İşletmeler ortalaması } \\
\text { Toplam }\end{array}$ & 1135 & 59.17 \\
Kapitalizasyon oranı & 14755 & 769.18 \\
\hline
\end{tabular}

Bölgede yapılan kamulaştırmalarda kapitalizasyon oranının $\% 5$ ve altında belirlendiği, ancak bu oranların seçilme nedenlerinin açıklanmadığı görülmektedir. Ülkemizde değişik bölgelerde yapılmış olan çalışmalarda bölgelerin; tarımsal arazi yapıları, verimlilik seviyeleri, arazi arz ve talebinin özelliği, toprak yapısı gibi özelliklerinden dolayı doğal olarak çok farklı kapitalizasyon oranları tespit edilmiştir. Örneğin, Demircan ve Orhan (1992) tarafindan Adana ili Seyhan ve Yüreğir ilçeleri kamulaştırma bölgelerinde yapılan çalışmada, kapitalizasyon oranı sulu tarla arazilerinde $\% 5,50$, kuru tarla arazilerinde $\% 4.97$ ve bölge ortalaması ise \%5,33 olarak saptanmıştır. Karakayacı ve Oğuz (2006) tarafindan Konya ili Ereğli ilçesi tarım arazilerinde kapitalizasyon oranını tespit etmek amacıyla yapılan çalışmada, kapitalizasyon oranını sulu tarla arazileri için \%6.02, kuru araziler için $\% 7.0$ ve ortalama kapitalizasyon oranı ise $\% 6.2$ olarak 
tespit edilmiş̧ir. Engindeniz (2001) ise Beydağ baraj göl alanında kalan tarım arazilerinin kamulaştırmalarında kullanılabilecek kapitalizasyon oranını \%4.48 olarak saptamışlardır. Oğuz ve Ünal (2004), Konya ili Çumra ilçesinde sulu tarım arazileri için kapitalizasyon oranını \%5.2 olarak tespit etmişlerdir. Sayılı ve Esengün, (1996) Tokat ili Kosova yöresinde sulu tarla arazileri için \%3.88, kuru tarla arazileri için ise \%3.31 olarak kapitalizasyon oranını tespit etmişlerdir. Keskin (1994) Eskişehir ilinde sulu tarla arazileri için kapitalizasyon oranını \%7.84, Aslan ve Esengün (2002) Tokat ili Artova ilçesinde sulu tarla arazileri için \%7.38, kuru tarla arazileri için ise \%6.19 kapitalizasyon oranı tespit etmişlerdir. Dağdemir ve ark. (2018), Ağrı'da kuru ve sulu alanalar için kapitalizasyon oranını sırasıyla 5.70 ve 5.31 olarak tahmin etmişlerdir. Bursa'da yapılan bir çalışmada ise, bu oranlar 5.75 ve 4.83 olarak tespit edilmiştir(Yalçın ve ark., 2018). Tüm bu çalışmalarla kıyaslandığında, Afşin-Elbistan ovası tarım arazileri için hesaplanan kapitalizasyon oranları

Çizelge 3. İncelenen işletmelerde uygulanan münavebe şekilleri

Table 3. Crop rotations applied in agricultural farms

Sulu arazilerde münavebe şekilleri

Buğday-Şekerpancarı

Buğday-Şekerpancar1-Buğday-Ayçiçeği

Buğday-Şekerpancarı-Buğday- Misır

Buğday-Şekerpancarı-Ayçiçeği-Mısır

Buğday

Sulanan alanlarda münavebeye giren ürün sayısı kuru arazilere oranla daha fazladır. Kuru arazilerde münavebeye giren ürünler; buğday, arpa ve nohut iken; sulu alanlarda buğday, şekerpancarı, ayçiçeği (çerezlik), misır, fasulye, arpadır. Ancak son yıllarda, bölgede fasulye ekim alanlarının önemli oranlarda azaldığı, buna karşılık mısır ekim alanlarının arttığı görülmektedir. İncelenen işletmelerde, fasulye ve arpanın münavebe sisteminde yer almaması nedeniyle, bu ürünler münavebe sisteminden çıkartılmıştır. İncelenen tarım işletmeleri termik santral kirliliğinden özellikle fasulyenin fazla etkilendiğini, buna bağlı olarak verimliliğin düşmesi ve pazar şartlarının iyi olmaması nedeniyle fasulye tarımından vazgeçtiklerini belirtmişlerdir. Bu ürünlerin dişında yer alan sebze ve meyve ürünleri (bağ, elma, kayısı vb) araştırma alanında fazla yer almadığından, münavebe uygulamalarına alınmamıştır.

Çizelge 4'de sulu alanlarda münavebeye giren ürünlerin verimleri, çiftçi eline geçen fiyatları, GSÜD, üretim masrafları ve net gelirler verilmiştir. Bölgede sulu alanlarda yetiştirilen ürünlerin ortalama verimleri; buğday tarımında $638 \mathrm{~kg} / \mathrm{da}$, şekerpancarında 7903 $\mathrm{kg} / \mathrm{da}$, ayçiçeğinde $206 \mathrm{~kg} / \mathrm{da}$ ve misırda $1022 \mathrm{~kg} / \mathrm{da}$ olarak saptanmıştır. Özellikle şekerpancarı üretiminde son yıllarda tohum verimliliği yüksek olan ithal tohum killeri kuru alanlarda sulu alanlara oranla daha yüksek bulunmuştur. Benzer bir sonuca, Demircan ve Orhan (1992), Oğuz ve Ünal (2004) ve Aslan ve Esengün (2002) ulaşırken; Dağdemir ve ark. (2018), Yalçın ve ark. (2018) ve Karakayacı ve Oğuz (2006) sulu araziler için hesaplanan kapitalizasyon oranını kuru arazilerden daha yüksek bulmuşlardır.

\subsection{Incelenen sulu ve kuru tarla arazilerinde münavebe sistemlerine göre net gelirler}

Örnek olarak seçilen işletmelerden arazi değerlerinin tespit edilmesi ve kapitalizasyon oranının tespiti amacıyla, sulu ve kuru tarla arazileri için ayrı ayrı arazi net gelirleri tespit edilmiştir. Araştırma sonuçlarına göre, termik santralinin civarında sulu ve kuru tarla arazilerinde, Çizelge 3'de gösterilen münavebe şekillerinin yaygın olarak kullanıldığı saptanmıştır.

\begin{tabular}{l}
\multicolumn{1}{c}{ Kuru arazilerde münavebe şekilleri } \\
Buğday-Arpa-Buğday \\
Buğday \\
Buğday-Nohut-Buğday \\
Buğday-Arpa-Nohut \\
Buğday-Nadas-Buğday \\
Arpa \\
Arpa-Nadas-Arpa
\end{tabular}

kullanılması nedeniyle, bölgede verimliliğin önemli oranda arttı̆g 1 ve $5000 \mathrm{~kg} / \mathrm{da}$ ile $10000 \mathrm{~kg} / \mathrm{da}$ arasında değiştiği belirlenmiştir. Buğday tarımında ise verimliliğin $400 \mathrm{~kg} / \mathrm{da}$ ile $1000 \mathrm{~kg} / \mathrm{da}$ arasında değişim gösterdiği saptanmıştır. Ayçiçeği verimi en fazla değişim gösteren ürünlerden biridir. İncelenen işletmelerde ayçiçeği verimliliği $100 \mathrm{~kg} / \mathrm{da}$ ile $350 \mathrm{~kg} / \mathrm{da}$ arasında değişim göstermektedir. Ayçiçeği verimliliğinin düşük olmasının nedenleri olarak genellikle termik santralin yaratmış olduğu kirlilik gösterilirken, bazı çiftçiler ise termik santralden ziyade geçmiş yıllarda hastalık ve zararlılardan dolayı verimliliğin önemli oranda düştüğünü belirtmişlerdir. Özellikle misır son yıllarda bölgede hızla münavebeye giren ürünler arasında yer almaktadır. Ortalama misır verimliliği $800 \mathrm{~kg} / \mathrm{da}$ ile $1200 \mathrm{~kg} / \mathrm{da}$ arasında değişmektedir. Proje alanında yapılan kamulaştırmalarda bilirkişilerin, Tarım İlçe Müdürlüklerinin resmi kayıtlarını da dikkate alarak verimlerin alt ve üst sınır değerlerinin ortalamasını alarak gelir analizi yaptıkları ve arazi değerlerini saptadıkları tespit edilmiştir. Ancak bu alt ve üst değerler önemli oranda değişim göstermekte olup, bu yolla elde edilecek bir ortalama verim değeri bölgede elde edilen ortalama verimlilik değerlerinden çok farklı olabilmektedir. Nitekim bölgede tarım kuruluşlarının 
resmi kayıtlarına göre, örneğin buğday verimlerinin alt ve üst değerleri sulu alanlar için $500 \mathrm{~kg} / \mathrm{da}$ ile $900 \mathrm{~kg} / \mathrm{da}$ arasında ve ortalama verim ise $700 \mathrm{~kg} / \mathrm{da}$ ' a göre arazi değerleri tespit edilmiştir. Mısırda verimlilik sınırları $900 \mathrm{~kg} / \mathrm{da}-1500 \mathrm{~kg} / \mathrm{da}$ ve ortalama verim $1200 \mathrm{~kg} / \mathrm{da}$; ayçiçeğinde ise verimlilik sınırları $250 \mathrm{~kg} / \mathrm{da}-350 \mathrm{~kg} / \mathrm{da}$ ve ortalama verim $300 \mathrm{~kg} / \mathrm{da}$ kabul edilerek arazi değerleri tespit edilmektedir. $\mathrm{Bu}$ ürün verimlerinin araştırma alanından elde edilen ürün verimleriyle karşılaştırıldığında, genel olarak daha yüksek olduğu tespit edilmiştir. İncelenen ürünler içerisinde sadece şekerpancarında verimlik düzeyi bölgede yer alan tarım kuruluşlarının vermiş olduğu rakamlardan daha yüksek elde edilmiştir. Bunun en önemli nedeni son yıllarda şekerpancarının verimlilik düzeyinin önemli oranda arttığı, ancak örneğe giren Elbistan ilçesine bağlı köy sayısının termik santrale yakın olmasından kaynaklı verimin daha az olmasıdır.

Gayrisafi üretim değeri (GSÜD), yaygın olarak yetiştirilen ürünlerin ortalama verimleri ile çiftçi eline geçen fiyatları çarpılarak bulunmuştur. Araştırmada bazı kurumlar tarafindan ilan edilen piyasa fiyatı yerine, doğrudan çiftçinin eline geçen net fiyatlar kullanılmıştır. Buğday, arpa ve nohutta yan ürün gelirleri dikkate alınmıştır. Diğer ürünlerde ise, çiftçiler yan ürün gelirlerini elde etmediklerinden hesapta dikkate alınmamıştır. Yan ürün gelirlerine bakıldığında, sulu alanlarda ortalama $287 \mathrm{~kg} / \mathrm{da}$ buğday samanı, kuru alanlarda ortalama $120 \mathrm{~kg} / \mathrm{da}$ buğday samanı, ve sulu alanlarda $110 \mathrm{~kg}$, kuru alanlarda ise $90 \mathrm{~kg} / \mathrm{da}$ arpa samanı elde edildiği tahmin edilmiştir. Buğday samanı fiyat1 $0.20 \mathrm{TL} / \mathrm{Kg}$, nohut samanı fiyatı ise $0.25 \mathrm{TL} / \mathrm{kg}$ olarak kullanılmıştır. Yan ürün fiyatları bölgede tarım kuruluşları ve çiftçi beyanları dikkate alınarak belirlenmiştir.

Bölgede yapılan kamulaştırma bedellerinin ödenmesinde bilirkişilerin yaptıkları en önemli hatalardan birisi de üretim masraflarını hesaplarken, genel idare giderleri ve sermaye faiz oranın dikkate almamalarıdır. İşletmenin sevk ve idaresi ile sosyal faaliyetler gibi hizmetlerin karşılığı olarak hesaplanan genel idare giderleri, tarımsal faaliyette yönetim işlerinin çoğunlukla işletme sahibi tarafından yapıldığı dikkate alındığında, masraflara eklenmesi gereken bir unsurudur (Kılıç, 2011b). Türkiye'de tarımla ilgili araştırmalarda genel idare giderleri hesaplanırken, işletmenin entansiflik dereceleri dikkate alınmakta, genellikle üretim masraflarının \%1-5 arasında değișen bir oran kullanılmaktadır (Kılıç, 2011b). Proje alanında bu oranın \%3 olduğu varsayımı dikkate alınmıştır. Döner sermaye faizi değişen bir masraf olup, üretim faaliyetine yatırılan sermayenin firsat maliyeti veya faizini temsil etmektedir (Karakayacı ve Oğuz, 2006; Erkuş ve ark., 1995). Üretim dönemi içerisinde değişik zamanlarda yapılan masrafların faiz karşılığı hesaplanırken, sermayenin üretimde kullanıldığı zaman dikkate alınmalıdır (K1lıç, 2011b). Bu çalışmada sermayenin üretimde kullanıldığı zaman dilimi ortalama 6 aylık bir süredir.

Toplam masrafların elde edilmesinde öncelikle arazi kirası hariç değişen masraflar tespit edilmiş ve bu masraflara \%3 genel idare giderleri ve \%6 sermaye faizi (Ziraat bankası yıllık tarımsal kredi faiz oranının yarısı) ilave edilmiştir. Aile iş gücü ücret karşıllı̆ııın hesaplanmasında, bölgede aynı iş için yabancı işçiye ödenen ortalama ücretler dikkate alınmıştır. Amaç arazi değerini tahmin etmek olduğundan, net gelir hesabında masraflar içerisinde arazi kirası yer almamaktadır (Kılıç, 2011b).

Tohum masrafi dekara atılan tohum miktarı ve çiftçinin ödemiş olduğu fiyat dikkate alınarak hesaplanmıştır. İşletmecinin kendi tohumunu kullandığı durumda ise ortalama piyasa fiyatları dikkate alınmıştır. İncelenen sulu tarım işletmelerinde dekara ortalama kimyasal gübre kullanımı; buğdayda $58 \mathrm{~kg} / \mathrm{da}$, şekerpancarında $140 \mathrm{~kg} / \mathrm{da}$, ayçiçeğinde $78 \mathrm{~kg} / \mathrm{da}$ ve misırda $80 \mathrm{~kg} / \mathrm{da}$ olduğu, kuru tarım arazilerinde ise; buğdayda $27 \mathrm{~kg} / \mathrm{da}$ arpada $29 \mathrm{~kg} / \mathrm{da}$ olduğu saptanmıştır. Bölge topraklarının PH seviyelerinin yüksek olması nedeniyle atılan bu gübre miktarının çok yüksek olduğu belirtilmektedir. Örneğin şekerpancarı tarımında gübre kullanımının $45 \mathrm{~kg} / \mathrm{da}$ ile $250 \mathrm{~kg} / \mathrm{da}$ arasında değişim gösterdiği belirlenmiş̧tir. Bu durum bölgede özellikle yayım faaliyetlerinin yetersiz, çiftçiler tarafindan ekonomik optimum gübre kullanım seviyelerinin dikkate alınmadığ 1 ve çiftçinin fazla gübre kullanımının fazla verim getireceği gibi yanlış bir düşünceye sahip olduğunu göstermektedir. Bu problemleri çözmek için, bölgede toprak tahlillerine dayalı bir gübrelemenin yapılması ve daha fazla gübre yerine yeterli ve dengeli gübre kullanımına dikkat edilmesi gereklidir.

Çizelge 4'den de görüleceği üzere, sulu tarım arazilerinde dekara en yüksek net gelirin şekerpancarından sağlandığı, bunu sırasıyla buğday, mısır ve ayçiçeğinin izlediği saptanmıştır.

İncelenen arazilerden elde edilecek rantların belirlenmesinde, arazilerde uygulanan münavebenin önemli bir etkisi bulunmaktadır. Buradan hareketle, incelenen arazilerden elde edilen toplam rant uygulanan münavebe sistemlerine göre Çizelge 5'de verilmiştir. Münavebe sistemine göre dekara elde edilen yıllık ortalama rantlar 297.8 TL (Buğday) ile 352.9 TL (Buğday-Şekerpancarı) arasında değişmektedir. En düşük ve en yüksek net gelire sahip olan münavebe sistemleri arasındaki fark yaklaşık 1.2 kat civarındadır. Çizelge 4'de verilen ve sulu tarım arazilerinde ürünler itibariyle elde edilen yıllık ortalama net gelirler arasındaki fark ise 1.6 kattır. $\mathrm{Bu}$ durum arazi değerlerinin tespitinde bölgede uygulanan yaygın münavebe sistemlerinin dikkate alınmasını ve buna göre arazi değerlerinin belirlenmesi gerektiğini göstermektedir. Örneğin en yüksek net gelire sahip olan münavebe sistemiyle en düşük gelire sahip olan münavebe sistemini kullanarak hesaplanacak arazi değerleri arasında $\% 5$ ve $\% 6$ kapitalizasyon oranlarına 
göre yaklaşık olarak sırasıyla $686 \mathrm{TL} / \mathrm{da}$ ile $572 \mathrm{TL} / \mathrm{da}$ kadar bir fark bulunmaktadır. Dolayısıyla bölgede yaygin olarak uygulanan münavebe sistemin kullanılması, arazi değerlerinin doğru bir şekilde tespit edilmesini sağlayacak ve haksızlığın önüne geçilmiş olacaktır.

Çizelge 4. İncelenen sulu tarım arazilerinde yıllık ortalama net gelirler

Table 4. Annual average net income in irrigated agricultural lands

\begin{tabular}{cccccccc}
\hline & \multicolumn{2}{c}{$\begin{array}{c}\text { Verimler } \\
(\mathrm{Kg} / \mathrm{da})\end{array}$} & $\begin{array}{c}\text { Çiftçi eline geçen fiyatlar } \\
(\mathrm{TL} / \mathrm{Kg})\end{array}$ & $\begin{array}{c}\text { GSÜD } \\
\text { (TL/da) }\end{array}$ & $\begin{array}{c}\text { Üretim } \\
\text { masrafları } \\
\text { (TL/da) }\end{array}$ & $\begin{array}{c}\text { Net Gelir } \\
\text { (TL/da) }\end{array}$ \\
\cline { 2 - 5 } Ürünler & Ana ürün & Yan ürün & Ana ürün & Yan ürün & & \\
\hline Buğday & 637.70 & 287.00 & 0.62 & 0.2 & 452.77 & 154.94 & 297.83 \\
Şekerpancar & 7903.45 & - & 0.12 & - & 908.90 & 500.86 & 408.04 \\
Ayçiçeği & 205.59 & - & 2.50 & - & 513.97 & 262.30 & 251.68 \\
Misır (dane) & 1022.00 & - & 0.49 & - & 500.78 & 229.03 & 271.75 \\
\hline
\end{tabular}

Çizelge 5. Değişik münavebe uygulamalarına göre sulu alanlarda yıllık ortalama net gelirler

Table 5. Annual net income in irrigated areas according to different crop rotation practices

\begin{tabular}{cccc}
\hline Yaygın münavebe sistemi & $\begin{array}{c}\text { GSÜD } \\
\text { (TL/da) }\end{array}$ & $\begin{array}{c}\text { Üretim } \\
\text { masrafları(TL/da) }\end{array}$ & $\begin{array}{c}\text { Net Gelir } \\
\text { (TL/da) }\end{array}$ \\
\hline Buğday-Şekerpancarı & 680.84 & 327.90 & 352.94 \\
Buğday-Şekerpancarı-Buğday-Ayçiçeği & 582.10 & 268.26 & 313.85 \\
Buğday & 452.77 & 154.94 & 297.83 \\
Buğday-Şekerpancarı-Ayçiçeği-Mısır & 594.11 & 286.78 & 307.33 \\
Buğday-Şekerpancarı-Buğday-Mısır & 578.81 & 259.94 & 318.86 \\
\hline
\end{tabular}

Çizelge 6'da kuru tarla arazilerinde münavebeye giren ürünler itibariyle ylllı ortalama net gelirler, Çizelge 7'de ise kuru tarım arazilerinde uygulanan münavebe sistemlerinin y1llık ortalama net gelirleri verilmiștir. Kuru tarla arazilerinde net gelirin en fazla elde edildiği ürün nohut iken, onu sirasiyla buğday ve arpa izlemektedir. Kuru tarım arazilerinde en fazla yıllık ortalama net gelirin buğday-nohut-buğday münavebesinden elde edildiği tespit edilmiştir. En az net gelir sadece arpanın dâhil edildiği münavebe sistemindedir. $\mathrm{Bu}$ münavebe sistemi bölgede aynı zamanda en fazla uygulanan münavebe sistemidir.
Yapılan anket çalışmalarında bu münavebe sistemini buğday-arpa-nohut münavebe sisteminin izlediği tespit edilmiştir. Net kar açısından bakıldığında ise, bu münavebe sistemi üçüncü sırada yer almaktadır. İkinci sırada sadece buğdayın yer aldığı münavebe uygulamasının olduğu saptanmıştır. Bu sonuçlar, kuru tarla arazileri için bölgede yaygın olarak uygulanan ve net gelir açısından da en yüksek net gelire sahip olan buğday-arpa-nohut münavebe sisteminin kamulaştırılacak arazilerin bedellerinin tespit edilmesinde dikkate alınması gerektiğini göstermektedir.

Çizelge 6. İncelenen kuru tarım arazilerinde yıllık ortalama net gelirler

Table 6. Annual average net income in the dry farmland

\begin{tabular}{|c|c|c|c|c|c|c|c|}
\hline \multirow[b]{2}{*}{ Ürünler } & \multicolumn{2}{|c|}{$\begin{array}{c}\text { Ortalama verimler } \\
(\mathrm{Kg} / \mathrm{Da})\end{array}$} & \multicolumn{2}{|c|}{$\begin{array}{l}\text { Çiftçi eline geçen } \\
\text { ortalama fiyatlar }\end{array}$} & \multirow[t]{2}{*}{$\begin{array}{l}\text { GSÜD } \\
\text { (TL/da) }\end{array}$} & \multirow{2}{*}{$\begin{array}{l}\text { Üretim } \\
\text { masraflar1 } \\
\text { (TL/da) }\end{array}$} & \multirow[t]{2}{*}{$\begin{array}{l}\text { Net gelir } \\
\text { (TL/da) }\end{array}$} \\
\hline & Ana ürün & Yan ürün & Ana ürün & Yan ürün & & & \\
\hline Buğday & 265.72 & 119.60 & 0.59 & 0.20 & 180.69 & 87.06 & 93.63 \\
\hline Arpa & 238.16 & 109.50 & 0.46 & 0.20 & 131.46 & 83.90 & 47.56 \\
\hline Nohut & 104.60 & 90.00 & 2.01 & 0.25 & 232.74 & 106.06 & 126.68 \\
\hline
\end{tabular}

Çizelge 7. Değişik münavebe uygulamalarına göre kuru arazilerde yıllık ortalama net gelirler Table 7. Annual net income in dry lands according to different crop rotation practices

\begin{tabular}{cccc}
\hline Yaygın Münavebe sistemi & $\begin{array}{c}\text { GSÜD } \\
\text { (TL/da) }\end{array}$ & $\begin{array}{c}\text { Üretim masrafları } \\
\text { (TL/da) }\end{array}$ & $\begin{array}{c}\text { Net gelir } \\
\text { (TL/da) }\end{array}$ \\
\hline Buğday-Arpa- Nohut & 181.63 & 92.34 & 89.29 \\
Buğday & 180.69 & 87.06 & 93.63 \\
Buğday-Nohut-Buğday & 198.04 & 93.39 & 104.65 \\
Buğday-Arpa-Buğday & 164.28 & 86.01 & 78.27 \\
Buğday-Nadas & 120.46 & 58.04 & 62.42 \\
Arpa- & 131.46 & 83.9 & 47.56 \\
Arpa-Nadas & 155.16 & 70.71 & 84.45 \\
\hline
\end{tabular}


3.3. Incelenen tarla arazilerinde gelir yöntemine göre arazi değerinin tespiti

Çıplak toprak değerlerinin tespitinde, bölgede yaygın olarak kullanılan münavebe sistemlerinin yıllık ortalama net gelirleri ve bölgede geçerli olan kapitalizasyon oranları bulunmuştur. $\mathrm{Bu}$ amaçla, yukarıda hesaplamış olduğumuz kapitalizasyon oranları ve hâlihazırda bölgede kullanılan kapitalizasyon oranları kullanılacaktır.

Araştırma alanında, \%5.76 ve diğer kapitalizasyon oranlarına göre en fazla arazi değeri buğdayşekerpancarı münavebesi uygulanan arazilerde görülmektedir (Çizelge 8). En düşük arazi değeri ise sadece buğdayın yer aldığı münavebe sisteminde bulunmuştur. Bölgede en fazla uygulanan münavebe sistemi buğday-şekerpancar1-ayçiçeği münavebe sistemi ile sadece buğday ve şekerpancarını içine alan münavebe sistemidir. Buğday-ş̧ekerpancarı-ayçiçeği münavebe sisteminde tespit edilen çıplak arazi değeri
(5448.8 TL/da) bölgede gerçekleşen alım satım değerlerinin ortalamasına (5666.7 TL/da) oldukça yakın olarak tespit edilmiştir. Bölgede sulu araziler için uygulanabilecek düşük bir (örneğin \%5.0) kapitalizasyon oranı ile yüksek bir kapitalizasyon oranı (örneğin \%6,5) arasındaki fark, arazi değerinin yaklaşık olarak $1629 \mathrm{TL} / \mathrm{da}$ farklı beyan edilmesine neden olabilecektir. $\mathrm{Bu}$ fark münavebe sistemleri arasındaki farklarda dikkate alındığında $2476 \mathrm{TL} / \mathrm{da}$ a kadar çıkabilmektedir.

Kuru tarla arazilerinde \%5.2 kapitalizasyon oranına göre en düşük arazi değeri $913 \mathrm{TL} / \mathrm{da}$ ile sadece arpaya yer verilen münavebe sisteminde bulunurken, en yüksek arazi değeri ise $2009 \mathrm{TL} / \mathrm{da}$ ile buğday-nohut-buğday münavebe sisteminde elde edilmiştir (Çizelge 9). Bölgede yaygın münavebe sistemi olan buğday-arpanohut münavebe sistemi ile buğday-nohut münavebe sisteminde arazi değerleri, bölgede gerçekleşen alım satım fiyatlarından daha yüksek tespit edilmiştir.

Çizelge 8. Farklı münavebe sistemleri ve kapitalizasyon oranına göre sulu arazi değerleri

Table 8. Irrigated land values according to different crop rotation systems and capitalization rate

\begin{tabular}{ccccccc}
\hline Münavebe sistemleri & Ortalama net & \multicolumn{5}{c}{ Kapitalizasyon oranlarına göre arazi değerleri (TL/da) } \\
\cline { 3 - 7 } & geliri (TL/da) & $\mathrm{f}=\% 5.76$ & $\mathrm{f}=\% 5.0$ & $\mathrm{f}=\% 5.5$ & $\mathrm{f}=\% 6.0$ & $\mathrm{f}=\% 6.5$ \\
\hline Buğday-şekerpancarı & 352.94 & 6127.43 & 7058.80 & 6417.09 & 5882.33 & 5429.85 \\
Buğday-şekerpancarı- & 313.85 & 5448.78 & 6277.00 & 5706.36 & 5230.83 & 4828.46 \\
Buğday-ayçiçeği & 297.83 & 5170.66 & 5956.60 & 5415.09 & 4963.83 & 4582.00 \\
$\quad \begin{array}{c}\text { Buğday } \\
\text { Buğday-şekerpancarı- }\end{array}$ & 307.33 & 5335.59 & 6146.60 & 5587.82 & 5122.17 & 4728.15 \\
Ayçiçeği-mısır & & & & & &
\end{tabular}

Çizelge 9. Farklı münavebe sistemleri ve kapitalizasyon oranına göre kuru arazi değerleri

Table 9. Dry land values according to different crop rotation systems and capitalization rate

\begin{tabular}{ccccccc}
\hline Münavebe sistemleri & Ortalama net & \multicolumn{4}{c}{ Kapitalizasyon oranlarına göre Arazi değerleri (TL/da) } \\
\cline { 2 - 6 } & geliri (TL/da) & $\mathrm{f}=\% 5.21$ & $\mathrm{f}=\% 5.0$ & $\mathrm{f}=\% 5.5$ & $\mathrm{f}=\% 6.0$ & $\mathrm{f}=\% 6.5$ \\
\hline Buğday-arpa- nohut & 89.29 & 1713.82 & 1785.80 & 1623.45 & 1488.17 & 1373.69 \\
Buğday & 93.63 & 1797.12 & 1872.60 & 1702.36 & 1560.50 & 1440.46 \\
Buğday-nohut-buğday & 104.65 & 2008.64 & 2093.00 & 1902.73 & 1744.17 & 1610.00 \\
Buğday-arpa & 78.27 & 1502.30 & 1565.40 & 1423.09 & 1304.50 & 1204.15 \\
Buğday-nadas & 62.42 & 1198.08 & 1248.40 & 1134.91 & 1040.33 & 960.31 \\
Arpa- & 47.56 & 912.86 & 951.20 & 864.73 & 792.67 & 731.69 \\
Arpa-nadas & 84.45 & 1620.92 & 1689.00 & 1535.45 & 1407.50 & 1299.23 \\
\hline
\end{tabular}

İncelenen işletmelere işledikleri arazinin satış değerleri konusundaki beklentileri sorulmuş ve elde edilen yanıtlar gelir yöntemine göre tahmin edilmiş olan çıplak arazi değerleri ile Çizelge 10 'da karşılaştırılmıştır. Sulu arazilerde arazi sahiplerinin arazilerine biçtikleri değerler ile \%5.76 kapitalizasyon oranı kullanılarak elde edilen arazi değeri arasındaki fark yaklaşık olarak $145.0 \quad \mathrm{TL} / \mathrm{da} \quad(\% 2.7)$ olarak bulunmuştur. Kuru arazilerde ise bu fark yaklaşı 554.6 TL/da'dır (\%32.4). Görüldüğü gibi, arazi sahiplerinin beklentileri ile gelir yöntemine göre hesaplanan arazi değeri arasındaki fark özellikle sulu arazilerde çok yakın iken, kuru arazilerde ise oldukça yüksektir. Bunun en önemli nedeni, işletmecilerin kuru arazilerden elde 154 ettikleri gelir çok düşük olduğu ve bu nedenle arazilerine yüksek bir değer biçmek istemediklerindendir. Ayrıca kuru tarla arazileri genellikle termik santralin daha uzağında yer almakta ve sulu arazilere göre kamulaştırılma ihtimalleri daha düşüktür. Sulu arazilerin bulunduğu alanlarda ise kamulaştırmalardan dolayı arazi talebi arzdan daha yüksektir, bu nedenle sulu arazilerde üreticilerin arazilerine biçtikleri değer daha yüksek belirtilmiştir.

Bölgede kira değerleri dikkate alınarak arazi değerleri tespit edildiğinde, gelir yöntemine arazi değerleri daha düşük tespit edilmiştir. Araştırma alanında incelenen işletmelere üzerinde tarım yaptıkları arazilerin yaklaşık kira değerleri sorulmuş ve bu 
değerler hesaplanan kapitalizasyon oranına bölündüğünde elde edilen arazi değeri kuru araziler için $867 \mathrm{TL} / \mathrm{da}$, sulu araziler için ise $1785 \mathrm{TL} / \mathrm{da}$ 'dır. Bu değerler gelir yöntemine göre hesaplanan değerlerden oldukça düşüktür. Bunun en önemli nedenleri bölgede kira talebinin fazla yoğun olmaması ve kiraların kuru tarla arazilerinde verimlilik düzeylerine göre $12.5 \mathrm{TL} / \mathrm{da}$ ile $100 \mathrm{TL} / \mathrm{da}$ arasında değişim göstermesi, sulu alanlarda ise, verimlilik düzeyleri ile yetiştirilecek ürüne göre $50 \mathrm{TL} / \mathrm{da}$ ile $200 \mathrm{TL} / \mathrm{da}$ arasında değişim göstermesidir.

Çizelge 10. İncelenen işletmelerde arazi sahiplerinin arazilerine biçtikleri değer ile gelir değerlerinin karşılaştırılması

Table 10. Comparison of the landowners' value on their lands with their net income values in agricultural farms

\begin{tabular}{ccccc}
\hline Arazi nevileri & $\begin{array}{c}\text { Değer beklentisi } \\
\text { (TL/da) (1) }\end{array}$ & $\begin{array}{c}\text { Gelir değeri } \\
\text { (TL/da) (2) }\end{array}$ & $\begin{array}{c}\text { Fark } \\
(2-1)\end{array}$ & Oran \\
\hline $\begin{array}{c}\text { Sulu tarla arazisi } \\
\text { (Buğday-şekerpancar1- ayçiçeği-buğday) } \\
\begin{array}{c}\text { Kuru tarla arazisi } \\
\text { (Buğday-arpa-nohut) }\end{array}\end{array}$ & 5303.80 & 5448.78 & 144.98 & 2.66 \\
\hline
\end{tabular}

Bölgede kira değerleri dikkate alınarak arazi değerleri tespit edildiğinde, gelir yöntemine kiyasla arazi değerleri daha düşük tespit edilmiștir. Araştırma alanında incelenen işletmelere üzerinde tarım yaptıkları arazilerin yaklaşık kira değerleri sorulmuş ve bu değerler hesaplanan kapitalizasyon oranına bölündüğünde elde edilen arazi değeri kuru araziler için $867 \mathrm{TL} / \mathrm{da}$, sulu araziler için ise $1785 \mathrm{TL} / \mathrm{da}$ 'dır. $\mathrm{Bu}$ değerler gelir yöntemine göre hesaplanan değerlerden oldukça düşüktür. Bunun en önemli nedenleri bölgede kira talebinin fazla yoğun olmaması ve kiraların kuru tarla arazilerinde verimlilik düzeylerine göre $12.5 \mathrm{TL} / \mathrm{da}$ ile $100 \mathrm{TL} / \mathrm{da}$ arasında değişim göstermesi, sulu alanlarda ise, verimlilik düzeyleri ile yetiştirilecek ürüne göre $50 \mathrm{TL} / \mathrm{da}$ ile $200 \mathrm{TL} / \mathrm{da}$ arasında değişim göstermesidir.

\section{Sonuç ve Öneriler}

$\mathrm{Bu}$ çalışmada, Afşin-Elbistan havzasında, tarla arazilerinin kıymet takdirini yapmak amaciyla kapitalizasyon oranı, net gelir ve maliyetler saptanmıştır. Bölgede sulu tarla arazileri için kapitalizasyon oranı \%5.76 olarak saptanırken, kuru tarla arazileri için ise \%5.21 olarak saptanmıştır. Bölgede uygulanan farklı münavebe sistemlerinin net gelirlerinde önemli farklılıkların olduğu, bu nedenle arazi değerlerinin tespitinde bölgede uygulanan yaygın münavebe sistemlerinin dikkate alınması ve buna göre arazi değerlerinin belirlenmesi gerekmektedir. Örneğin en yüksek net gelire sahip olan münavebe sistemiyle en düşük gelire sahip olan münavebe sistemini kullanarak hesaplanacak arazi değerleri arasında $\% 5$ ve $\% 6$ kapitalizasyon oranlarına göre yaklaşık olarak sırasıyla $686 \mathrm{TL} / \mathrm{da}$ ile $572 \mathrm{TL} /$ da kadar bir fark bulunmaktadır. Dolayısıyla bölgede yaygın olarak uygulanan münavebe sisteminin kullanılması, arazi değerlerinin doğru bir şekilde tespit edilmesini sağlayacak ve herhangi bir haksızlığın önüne geçilmiş olacaktır.

Buğday-şekerpancarı-ayçiçeği münavebe sisteminde tespit edilen çıplak arazi değeri (5448.8 TL/da) bölgede gerçekleşen alım satım değerlerinin ortalamasına (5666.7 TL/da) oldukça yakın olarak tespit edilmiştir. Bölgede sulu tarla arazileri için uygulanabilecek düşük bir (örneğin \%5.0) kapitalizasyon oranı ile yüksek bir kapitalizasyon oranı (örneğin \%6.5) arasındaki fark arazi değerinin yaklaşık olarak $2476 \mathrm{TL} / \mathrm{da}$ farklı beyan edilmesine neden olabilecektir. Kuru tarla arazilerinde \%5.2 kapitalizasyon oranına göre en düşük arazi değeri $913 \mathrm{TL} / \mathrm{da}$ ile sadece arpaya yer verilen münavebe sisteminde bulunurken, en yüksek arazi değeri ise 2009 TL/da ile buğday-nohut münavebe sisteminden elde edilmiştir. Bölgede yaygın münavebe sistemi olan buğday-arpa-nohut münavebe sistemi ile buğday-nohut münavebe sisteminde arazi değerleri, bölgede gerçekleşen alım satım fiyatlarından daha yüksek tespit edilmiştir. Tarımsal kıymet takdiri ve kapitalizasyon oranının hesaplanmasıyla bölgede uygulanacak kamulaştırmalarda kamu kurum ve yargı organlarına önemli katkılarda bulunacaktır.

\section{Teșekkür}

Bu çalışma, TÜBİTAK tarafindan desteklenmiş projenin bir bölümünden alınmıştır.

\section{Kaynaklar}

Akay, M., Akçay, Y. ve Sayılı, M., 2001. Tokat ili Erbaa ovası tarla arazilerinde kapitalizasyon faiz oranı üzerine bir araştırma. Kooperatifçilik Dergisi, Türk Kooperatifçilik Kurumu Yayını, 131: Ocak-Mart, Ankara

Aktaş, A.R., 2000. Tokat ili Niksar ovası tarla arazilerinde kapitalizasyon faiz oranının saptanması üzerine bir araştırma. Yüksek lisans tezi (yayımlanmamış). Gaziosmanpaşa Üniversitesi Fen Bilimleri Enstitüsü Tarım Ekonomisi Anabilim Dalı, Tokat.

Aslan, İ., 2002. Tokat ili Artova ilçesi tarla arazilerinde kapitalizasyon faiz oranının tespiti üzerine bir araştırma. GOÜ. Fen Bilimleri Enstitüsü Tarım 
Ekonomisi Anabilim Dalı, Yüksek Lisans Tezi, Tokat.

Anonim, 2019. Kamulaştırma kanunu. https://www.mevzuat.gov.tr/MevzuatMetin/1.5. 2942.pdf (Erișim tarihi: 19.08.2019).

Avcı, İ. ve Akay, M., 2012. Tokat ili Pazar ilçesi tarla arazilerinde kapitalizasyon oranının tespiti. GOÜ, Ziraat Fakültesi Dergisi, 29(1), 65-74.

Aydın, H. ve Akay, M., 2008. Zile ovası tarla arazilerinde kapitalizasyon oranının tespiti üzerine bir araştırma. GOÜ Ziraat Fakültesi Dergisi, 25(1): 23-31.

Başer, U. ve Kılıç, O., 2016. Arazi fiyatını etkileyen faktörlerin belirlenmesi: (Samsun İli, Ladik İlçesi). Türkiye XII. Ulusal Tarım Ekonomisi Kongresi, 25-27 Mayis, Isparta, Cilt-1, 273-280.

Başer, U., Kılıç, O., Abacı, H.S. 2019. Arazi fiyatını etkileyen faktörlerin doğrudan ve dolaylı etkilerinin Path Analizi ile belirlenmesi: Samsun ili Ladik ilçesi örneği. Türkiye Tarımsal Araştırmalar Dergisi, 6(1): 50-56.

Birinci, A., 1997, Erzurum ve Erzincan illerinde tarla arazilerinin kıymetlerinin takdirinde kullanılan kapitalizasyon faizine etki eden faktörlerin tespiti üzerine bir araştırma. Doktora Tezi, Atatürk Üniversitesi Fen Bilimleri Enstitüsü, Erzurum.

Dağdemir, V., Aşkan, E., Demir, O. ve Tercan, S. 2018. Ağrı ili merkez ilçe tarım arazilerinde kapitalizasyon oranının tespiti. Alinteri J. of Agr. Sci. 33(2): 133-139. Doi: 10.28955/alinterizbd.384530.

Demircan, V. ve Orhan, E., 1992. Adana ili Seyhan ve Yüreğir ilçeleri kamulaştırma bölgesindeki tarla arazilerinin kıymet taktirinde uygulanabilir kapitalizasyon faiz oranının saptanması. ÇÜ. Ziraat Fakültesi Dergisi, 7(2): 115-128.

Engindeniz, S., 2001. Beydağ baraj göl alanında kalan tarım arazilerinin kamulaştırılmasında kullanılabilecek kapitalizasyon faiz oranının saptanması üzerine bir araştırma. EÜ. Ziraat Fakültesi Derisi, 38(2-3): 95-102.

Erkuş, A., Bübül, M., Kıral, T., Açıl, A.F., Demirci, R., 1995, Tarım ekonomisi, A.Ü. Zir. Fak. Eğitim, Araştırma ve Geliştirme Vakfı Yayın No:5, Ankara, $298 \mathrm{~s}$.

Gündoğmuş, M.E ve Taşçı, M. 2017. Hünnap (Zizyphus jujube mill.) Bahçelerinde gelir yöntemine göre değerleme: Denizli ili Çivril ilçesi örneği. Tekirdağ Ziraat Fakültesi Dergisi, 4(02): 42-53.

Kalkan, M., 2008. Bilirkiși el kitabı. TMMOB Ziraat Mühendisleri Odası, Teknik Yayınlar Dizisi, No: 6. Ankara.

Karakayacı, Z., Oğuz, C., 2006. Konya ili Ereğli ilçesi tarım arazileri için kapitalizasyon oranının tespiti. SÜ Ziraat Fakültesi Dergisi, 20(40): 2126.
Keskin, G., 1994. Eskişehir ili tarla arazilerinde ortalama kapitalizasyon faiz oranının bulunması üzerine bir araştırma. AÜZF Tarım Ekonomisi Bölümü Yayınlanmamış Yüksek Lisans tezi, Ankara.

Keskin, G., 2003. Tarım arazilerinin kamulaştırılmasında değer biçme: Akyar Barajı örneği. Akdeniz İ.İ.B.F. Dergisi (5): 91-107

Kılıç, O., 2011a. Kamulaştırma davalarında arsa-arazi ayrımı". Akdeniz Üniversitesi Ziraat Fakültesi Dergisi, 24(1): 15-18.

Kılıç, O., 2011b. Tarım arazisi için kapitalizasyon oranının hesaplanması. Anadolu Tarım Bilim Dergisi, 26(2): 181-187.

Neupane A., Gustavson, K., 2008. Urban property values and contaminated sites: A Hedonic Analysis of Sydney, Nova Scotia. Journal of Environmental Management, 88: 1212-1220

Oğuz, C., Ünal, Z., 2004. Konya ili Çumra ilçesi sulu tarım arazilerinde kapitalizasyon faiz oranı tespiti. S.Ü. Ziraat Fakültesi Dergisi, 33(18): 816.

Sayıl1, M., Esengün, K., 1996. Tokat ili Kozova yöresi tarla arazilerinde kapitalizasyon faiz oranının saptanması üzerine bir araştırma. GOP Ünv. Ziraat Fakültesi Dergisi, 13(1): 211-133.

Tanrıvermiş, H., Aliefendioğlu, Y., 2008. Türkiye'de kamulaştırma amaçlı değerleme raporlarının değerleme teknikleri yönünden analizi, A.Ü. Fen Bilimleri Enstitüsü Taşınmaz Geliştirme Anabilim Dalı Yayın No:3, Ankara.

Tanrıvermiş, H., Akipek, Ş., Bayramin, İ., Gün, A.S., Aliefendioğlu, Y., 2008. Ermenek Baraj1 ve hidroelektrik santrali projesi kamulaştırma alanındaki arazilerin gelirleri, kapitalizasyon oranları ve birim arazi değerlerinin araştırılması. A.Ü. Fen Bilimleri Enstitüsü Taşınmaz Geliştirme Anabilim Dalı Yayın No:1, Ankara.

Yalçın, G., Selçuk, O. ve Şentürk, E., 2018. Bursa ili Mustafakemalpaşa ilçesi tarım arazilerinde kapitalizasyon oranının tespiti. AKU J. Sci. Eng.18: 548-560.

Yamane, T., 1967. Elementary sampling Theory. Prentice Hall, Englewood Cliffs, NJ. 